\title{
Is There a Racial Wage Gap in Research Libraries? An Analysis of ARL Libraries
}

\author{
Quinn Galbraith, Heather Kelley, and Michael \\ Groesbeck
}

\begin{abstract}
Racial equality has been of great importance to the Association of Research Libraries (ARL), as seen through various initiatives. However, in recent years, little research has been done regarding the racial wage gap in ARL libraries. Researchers used thirty-five years of raw ARL salary survey data to examine the wage gap between racial minorities and nonminorities (whites). Using this data, researchers created a model that controlled for institution, years of experience, years of experience squared, position, law or medical library, and sex to better understand the nature of the racial wage gap. This model shows that the gap has gradually closed over the years and that there is no longer a statistically significant wage gap between racial minorities and nonminorities in ARL libraries today.
\end{abstract}

An important question often asked in organizations is whether there is a pay disparity in salaries between minorities and nonminorities. Racial equality is an important concern across the United States and-as evidenced by various diversity initiatives that will be reviewed briefly - is of great importance to ARL libraries. As ARL consists of more than 100 academic libraries scattered across North America, an examination of ARL libraries may provide valuable insights into the profession as a whole. One measure of racial equality that has been understudied is pay equity in ARL libraries. This study attempts to address the issue of pay equity by discussing the current state of the racial wage gap and how it has changed in recent years. This is done by primarily focusing on the current state of the racial wage gap, looking specifically at ARL's 2014 Salary Survey data and by presenting data from the past thirty-five years to show minority trends. Researchers examined the data with the expectation that the racial wage gap would have decreased over the past thirty-five years. Understanding where the racial wage gap is today compared to where it was will be important to the various ARL diversity committees as they continue to make strides toward ensuring racial equality for all their employees. As such, and to further contextualize the current

Quinn Galbraith is Sociology and Family Life Librarian, Heather Kelley is a Research Assistant, and Michael Groesbeck is a Research Assistant, all in the Harold B. Lee Library at Brigham Young University; emails:quinn_galbraith@byu.edu, heather_kelley@byu.edu,and mdgroesbeck@gmail.com. Special thanks to Jessica Mansfield for her significant contributions in editing this paper and to Labor Economist Brigham Frandsen, PhD, for his consulting assistance. (C2018 Quinn Galbraith, Heather Kelley, and Michael Groesbeck, Attribution-NonCommercial (http://creativecommons.org/licenses/by-nc/4.0/) CC BY-NC. 
state of the racial wage gap in academic libraries, this report will offer a brief history of diversity initiatives in ARL libraries as well as in Library and Information Science (LIS) graduate programs.

According to Blixrud and George's pamphlet ${ }^{1}$ celebrating ARL's seventieth birthday, the Higher Education Act Title II-B, passed in 1965, introduced the need to improve recruiting, training, and retention techniques in ARL libraries, particularly for minority librarians. This led ARL to create a program that was eventually named the Office of Leadership and Management Services (OLMS). During this time, OLMS worked to address the growing concerns of diversity among ARL members. It was not until 1991 that the organization received enough grants to hire a part-time diversity consultant and simultaneously establish the Meeting the Challenges of a Culturally Diverse Workforce program. ${ }^{2}$ Only a few years later, in 1994, ARL received another grant that allowed them to establish a full-time diversity program. ${ }^{3}$ Two major programs have stemmed from ARL's diversity program: the Leadership and Career Development Program (LCDP) in $1997,{ }^{4}$ followed by the Initiative to Recruit a Diverse Workforce (IRDW) in 2000. ${ }^{5}$

These initiatives took place under the direction of Duane Webster, who joined ARL in 1970 and was employed by the organization until his retirement in 2008. Many have lauded his work in establishing and advancing diversity initiatives in academic libraries. Webster was concerned with minority status in libraries from the time he began his employment with ARL in 1970 until he retired thirty-eight years later. ${ }^{6}$ In a 1972 publication, after conducting interviews with fifty-two of the seventy-eight ARL libraries, Webster suggested improving employment conditions for minorities by establishing "library and university personnel policies, and the establishment of concrete specific library and organizational unit goals, ${ }^{17}$ among other suggestions.

In 2009, Barbara Dewey, dean of University Libraries and Scholarly Communications at Penn State University, reviewed the progress of ARL's goals and initiatives, as well as some of the progress resulting from individual library goals. Dewey states that "universities, far and wide, have specific initiatives to integrate intercultural and international initiatives into every aspect of the campus experiences and its outcomes." ${ }^{18}$ She goes on to claim that all students, faculty, and staff benefit from these initiatives. ${ }^{9}$ Lori Mestre, head of the Undergraduate Library and Professor of Library Administration at the University of Illinois: Urbana-Champaign, also affirms the importance of diversity within academic libraries. Mestre believes that using a library's website could be an effective way to display diversity information, as the website is "the first and possibly only interaction that students have with the library." ${ }^{10}$ In 2011, Mestre conducted a study reviewing every ARL member website in the United States and searching for visibility of diversity elements. Mestre's results show that 37 percent of ARL libraries' websites in the United States openly included diversity in their strategic plan or in their values or vision statement on their web pages. However, Mestre notes that more research needs to be done to measure the impact of these goals and programs in promoting racial diversity and equality.

Mestre concludes her article by recommending that diversity is made more visible on library websites. ${ }^{11}$ Her final suggestion states that the value of diversity should permeate every aspect of the organization. ${ }^{12}$ Franklin and Jaeger ${ }^{13}$ would extend this to include fostering diversity in Library and Information Science programs, as they find that diversity within libraries begins with diversity in LIS programs.

\section{Literature Review}

Considering that the United States is one of the most diverse countries in the world, it is no wonder that diversity initiatives have become a major focus for organizations. While much research has been done on the racial wage gap across various professions, 
there is little research regarding the current state of the gap in ARL libraries. Researchers will thus give an overview of the limited literature regarding current issues and trends that may impact the current state of the racial wage gap in academic libraries. Although the focus of this paper is primarily on wage disparity between minorities and nonminorities, this paper will briefly address the number of minorities employed in academic libraries. Therefore, the researchers will begin with an overview of racial diversity in LIS programs, as the vast majority of academic librarians first attend these programs. They will then discuss the most current research on the racial wage gap in academic libraries as well as some of the literature on the wage gap in academia in general. The literature review will conclude by presenting variables that may help explain the racial wage gap.

In 2005, approximately 26.4 percent of students enrolled in graduate programs were racial or ethnic minorities, but only 11.3 percent of those enrolled in LIS programs accredited by the American Library Association (ALA) were racial or ethnic minorities. ${ }^{14}$ Kim and Sin call this gap "a serious issue"15 and warned that this gap between LIS minorities and the U.S. population would widen further if more aggressive recruitment techniques were not implemented. ${ }^{16}$ Related to this concern, Kim and Sin conducted a study looking at minority recruitment and retention in LIS masters' programs. They sampled librarians of color on their satisfaction with the LIS program's diversity recruitment and retention efforts.

The results of the study show that, with the exception of students participating in distance-learning curriculum recruitment and retention, efforts in LIS programs to increase enrollment of racially diverse students have not been particularly successful. ${ }^{17}$ Kim and Sin then give the following three suggestions to improve minority recruitment: hire more faculty of color at LIS institutions; offer more scholarships and financial aid (also crucial in retention); and recruit more actively and creatively. Kim and Sin continue their analysis by breaking down recruitment and retention strategies according to race and find distinct differences between what different ethnic groups feel are effective techniques. This leads Kim and Sin to warn against lumping different ethnic groups under the single title of "minority," positing that racial/ethnic groups may have "different views and need different recruitment/retention strategies."18

Indeed, there are several articles focusing specifically on the needs of particular minority groups within library science. For example, one qualitative study presents the lack of community involvement in LIS schools as being particularly difficult for Latinos because community is a very important part of their cultural identity. ${ }^{19}$ A study on American Indians shows that their concerns are completely different from those of Latinos. In this study, the author posits that the underrepresentation of American Indian librarians has led to an underrepresentation of American Indian literature in library collections..$^{20}$ According to the author, this underrepresentation is also related to librarians not understanding the complex and differing backgrounds American Indian students come from, preventing them from connecting and properly serving these patrons. One final example is that of Karin Griffin, a black female academic librarian, who writes of the challenges she faced as a black female, including not fitting into the traditional academic culture and feeling "the need to quell the myth of presumed incompetence." ${ }^{21}$ Consistent with the differences demonstrated in these narratives, Griffin notes the need for more research focusing on the needs and status of specific racial/ethnic groups of academic librarians. ${ }^{22}$

While the literature is very clear that a large difference between the number of racial/ ethnic minorities and whites in LIS schools exists, the relationship between minority status and salary for LIS graduates is less clear. In 2009, Morgan, Farrar, and Owens examined the salaries of LIS graduates and found that blacks and whites made close 
to the same amount, and Asians reported actually earning more than whites. Although these results are interesting, they are of limited relevance to the racial wage gap in academic libraries, as Morgan et al. did not examine pay in libraries specifically, and LIS graduates enter many professions outside librarianship. For example, 48.78 percent of Asians in this study went into a nonlibrary career. ${ }^{23}$ Thus, we now turn to the research that has been done specifically regarding the racial wage gap in libraries.

Despite the growing awareness of minority status in libraries during the past forty years, ${ }^{24}$ few studies have actually explored the racial wage gap in libraries; and most of the studies that have looked at the racial wage gap have conducted only a simple analysis of comparing the means. ${ }^{25}$ In 2010, Sweeper and Smith explored the racial wage gap in library science using a regression analysis that allowed them to control for variables that may have been influencing the gap. Their data sample consisted of 357 college graduates working in library science who participated in the 2003 National Survey of College Graduates (NSCG). The authors' analysis found that there were no significant differences among racial groups. While these findings were shocking and exciting to many, there are several limitations to this study in regard to measuring the racial wage gap in academic libraries. Sweeper and Smith's data did not include what position the respondent held or whether or not the respondent had an advanced degree in library science. ${ }^{26}$ An additional limitation of the study, due to the small sample size, was that there were not enough responses to allow the authors to distinguish among academic, public, private, and/or special libraries. ${ }^{27}$ Finally, the data they used in this study is dated. However, the literature searches conducted for this paper did not yield any more recent studies focused specifically on the racial wage gap in libraries.

Considering the limited amount of research that has been conducted on the racial wage gap in academic libraries, it is useful to explore the literature regarding the racial wage gap among academic faculty members, as they are very similar to academic librarians. However, there is not an abundance of research in this area either, perhaps because earlier studies did not find much evidence of a racial wage gap among academic faculty members. ${ }^{28}$ A more recent study used regression models to find that race only impacted the salary of Asians on a statistically significant level, showing that Asians made more than their white counterparts. ${ }^{29}$

The research on the racial wage gap among academic librarians is clearly limited, a problem that this article strives to address. While ARL's Annual Salary Surveys provide the most up-to-date statistics on the racial wage gap in ARL libraries, ARL's published surveys do not control for variables that may impact salary. Institution, position, years of experience, and years of experience squared are all widely accepted as variables that impact salary and should therefore be controlled for when measuring salary differences between two groups. ${ }^{30}$ It is necessary to control for institution because pay varies from one library to another. Renzulli, Grant, and Kathuria investigated the impact different institutions have on pay gaps among faculty in universities, looking closely at the differences between predominantly white institutions (PWIs) and historically black colleges and universities (HBCUs). They found that the average salary for both men and women in HBCUs was lower than in PWIs. Men in HBCUs earned \$5,349 less on average than those in PWIs, and women earned approximately $\$ 2,000$ less in HBCUs than their female PWI counterparts. To control for the many variables that differ within institutions, the authors also controlled for the size of tenure-track faculty, the geographical region, and the institution type (that is to say, medical, public/private, religiously affiliated, and the like). ${ }^{31}$

Position is another factor that has a strong effect on salary. From his study of the gender wage gap among librarians, David Dowell, after using twenty variables to explain the wage gap, determined that the most powerful predictor of salary was 
position level. ${ }^{32}$ Research also shows that it is important to control for both years of experience and years of experience squared as additional years of experience do not always result in equivalent pay increases. ${ }^{33}$ For example, in an institution that offers tenure, the advancement from six years of experience to seven years of experience will be associated with a large increase in pay, whereas the advancement from fifteen to sixteen years of experience will not be associated with such a large pay increase.

Although the focus of this paper is on the racial wage gap, gender is another factor that should be addressed. Galbraith et al. explored the gender wage gap in ARL libraries in depth and found that, even after accounting for seven variables (years of experience, years of experience squared, location, institution, position, marital status, and number of children at home), the wage gap between male and female academic librarians was still statistically significant, though it was quite small (approximately a 2 percent gap). ${ }^{34}$

In addition to these well-accepted and acknowledged factors used in most standard wage gap models, there are also many other potential, less-researched variables that may influence the racial wage gap. Among these variables are general levels of happiness, ${ }^{35}$ perceptions of fair compensation, ${ }^{36}$ differences in salary due to the number of children, ${ }^{37}$ and marital status. ${ }^{38}$

\section{Methodology}

As a Visiting Program Officer for the Association of Research Libraries, the primary researcher was granted access to thirty-five years of raw ARL Salary Survey data. Although ARL publishes this data annually in aggregate form, this raw data has never before been analyzed to find an adjusted wage gap. While the salary reports that ARL publishes annually are highly informative, this raw racial wage gap may be misleading when other factors affecting it, unrelated to race, are not accounted for. ${ }^{39}$

The terms raw wage gap and adjusted wage gap are used frequently throughout this paper to describe wage differences between minorities and nonminorities. To contextualize the difference in salary, the percent difference-what one group earns as a percentage of another-is generally reported rather than the actual gap. Thus, if one group makes 100 percent of what the other group makes, this means that there is no pay difference between the two groups. The lower the percentage, the larger the wage gap. In this context, the raw wage gap refers to a comparison of mean salaries. For example, if the mean nonminority salary was $\$ 100,000$ and the mean minority salary was $\$ 95,000$, then the raw gender wage gap would be reported as minorities making 95 percent of what nonminorities make. While this number is informative, it does not by itself establish the existence of a disparity in pay. Differences in human capital could explain why a group appears to be paid less. Therefore, an adjusted wage gap should be calculated that controls for such differences. In other words, the adjusted wage gap is an estimate of what a person of one group would earn compared to a person of the comparison group with the same characteristics (including position, years of experience, institution).

Researchers used ARL's Salary Survey data from 1980 to 2014. This data includes the race, sex, institution, position, and salary of all ARL library employees. Each year ARL sends its member libraries the annual salary survey. Each library designates a survey coordinator who responds to the survey for all applicable employees within their organization. Since this information is private information, the coordinator is often the HR manager or another administrative employee in the library. Since all ARL member libraries respond to the survey, the number of respondents should equal close to 100 percent of the applicable population. Thus, this study is based on data from the entire ARL population.

While this study's analysis focuses primarily on the current state of the racial wage gap by analyzing the 2014 data, the adjusted wage gap is also calculated for all thirty-five 
years to show trends related to the racial wage gap. This data does not include information from deans and directors, causing the researchers to exclude heads of law and medical libraries to maintain consistency within the data. ARL's data does include part-time employees with their projected full-time salary; however, only full-time employees are included. As Canadian law prohibits reporting and distributing any racial information on employees, all Canadian schools are excluded from this analysis, and thus the sample consists of only librarians within the United States. With these constraints, there is information about 8,133 professional ARL librarians, 1,242 of which are minorities.

As the ARL Salary Survey is administered to all ARL libraries, the data can effectively be thought of as a census for the population of ARL library employees. Theoretically, any differences in the data should represent the actual population difference. However, because observations reveal salary fluctuations and noise from year to year, tests of significance are reported as if the data had been a sample drawn from a larger population. In this way, the data can be thought of as a sample of ARL librarians and would not be considered a census.

All minorities $(n=1,242)$ in the ARL data were first analyzed together and then separated for further analysis into three groups: blacks $(n=386)$, Asians/Pacific Islanders $(n=571)$, and Hispanics $(n=253)$. American Indians were not analyzed separately, as there were only thirty-two American Indians in the data. Regression models were developed to analyze salary differences while accounting for a number of different variables. The original model, used to measure salary differences between racial minorities and nonminorities, was defined as:

$$
\ln (\text { salary })=\alpha+\beta \cdot \mathrm{X}+\varepsilon
$$

In this model, $\ln$ (salary) represents the natural logarithm of the respondents' yearly salary, $\alpha$ represents the intercept of the equation, $\beta$ is a vector of coefficients that ties each of the explanatory variables to salary, and $\varepsilon$ is a vector of random error terms. $X$ is a matrix of explanatory variables that could affect respondents' salary. This matrix included years of experience, years of experience squared, institution worked at, job position, indicators for law and medical librarians, sex, and an indicator of minority status. Dummy variables were used for each institution and job position. The standard errors were clustered at the institutional level and used to compute confidence intervals and determine significance of variables. Clustering was used, as it allows for arbitrary correlation among respondents at the same institution but assumes independence between institutions. The coefficient for the minority variable was then converted to a percentage by the formula $100-100 * \exp \left(\beta_{\text {minority }}\right)$. This model was used to estimate the wage gap for each of the thirty-five years in the data.

The racial wage gap was then analyzed by whether the respondents were black, Asian/Pacific Islander, or Hispanic. The same model used earlier was used here as well, but the model was run separately for each of the three groups. Each group was compared against the Caucasian/Other group. For example, the Hispanic wage gap was computed using a subset of the data containing only respondents who identified as Hispanic compared with Caucasian/Other. The minority coefficient then measured only the differences between those two groups. The racial wage gap for each group was adjusted by comparing each of the racial groups against the Caucasian/Other group.

\section{Results}

According to the 2014 raw ARL data, racial minorities earn 95.87 percent of what nonminorities earn. However, when institution, years of experience, years of experience squared, position, sex, and law/medical library are controlled for, the data shows that 
minorities earn 99.89 percent of nonminorities' salary, which is no longer statistically significant $(P=.021$; see table 1$)$. Because of the many differences that exist between minority groups, the gap was further analyzed by comparing blacks, Asians/Pacific Islanders, and Hispanics to nonminorities.

According to the raw data in 2014, blacks earn 96.57 percent of what nonminorities earn. When the study model was run, replacing "minority" with "blacks," the gap reversed, showing that blacks earn 100.73 percent of what nonminorities earn. This could be translated to mean that blacks, on average, actually earn more than their nonminority counterparts. However, as the difference is so small and not statistically significant $(P=.429)$, it is assumed that there are no differences in salary between blacks and nonminorities.

According to the raw data, Asians/Pacific Islanders earn 96.43 percent of what nonminorities earn. Running the original model but replacing "minority" with "Asian," the gap becomes 99.93 percent. This gap is also no longer statistically significant $(P=.934)$.

Hispanics account for the largest raw wage gap, earning only 92.54 percent of the average salary of nonminorities. However, when the model is run for Hispanics, it shows that they earn 97.78 percent of what nonminorities earn. While this is by far the largest difference, the wage gap is still not statistically significant $(P=.09)$. However, it is important to note that the gap may be considered marginally significant, as it is approaching statistical significance at the $P<.05$ level.

\begin{tabular}{|c|c|c|c|c|}
\hline \multicolumn{5}{|c|}{$\begin{array}{c}\text { TABLE } 1 \\
\text { Minority Wage Gap }\end{array}$} \\
\hline & \multicolumn{4}{|c|}{$\begin{array}{l}\mathrm{N}=8,245 \\
\log \text { (salary) }\end{array}$} \\
\hline & 1 & 2 & 3 & 4 \\
\hline Minority & $\begin{array}{c}0.032 * * * \\
(0.011) \\
\end{array}$ & $\begin{array}{c}0.005 \\
(0.010) \\
\end{array}$ & $\begin{array}{l}-0.012 \\
(0.010) \\
\end{array}$ & $\begin{array}{c}0.001 \\
(0.007) \\
\end{array}$ \\
\hline Experience & & $\begin{array}{c}0.026 * * * \\
(0.001) \\
\end{array}$ & $\begin{array}{c}0.021 * * * \\
(0.001) \\
\end{array}$ & $\begin{array}{c}0.019 * * * \\
(0.001) \\
\end{array}$ \\
\hline Law & & & & $\begin{array}{l}0.027 * \\
(0.014) \\
\end{array}$ \\
\hline Medical & & & & $\begin{array}{c}-0.066^{* * *} \\
(0.015)\end{array}$ \\
\hline Male & & & & $\begin{array}{c}0.023 * * * \\
(0.005)\end{array}$ \\
\hline \multirow[t]{2}{*}{ Constant } & $11.154 * * *$ & $10.860 * * *$ & $10.896^{* * *}$ & $10.790 * * *$ \\
\hline & $(0.014)$ & $(0.016)$ & $(0.025)$ & $(0.021)$ \\
\hline School? & No & No & No & Yes \\
\hline Position? & No & No & Yes & Yes \\
\hline Clustered SE? & Yes & Yes & Yes & Yes \\
\hline $\mathrm{R}^{2}$ & 0.002 & 0.281 & 0.501 & 0.665 \\
\hline Adjusted $\mathrm{R}^{2}$ & 0.001 & 0.281 & 0.500 & 0.660 \\
\hline $\begin{array}{l}\text { Residual Std. } \\
\text { Error }\end{array}$ & $\begin{array}{c}0.300 \\
(\mathrm{df}=8,243)\end{array}$ & $\begin{array}{c}0.254 \\
(\mathrm{df}=8,241)\end{array}$ & $\begin{array}{c}0.212 \\
(\mathrm{df}=8,222)\end{array}$ & $\begin{array}{c}0.175 \\
(\mathrm{df}=8,117)\end{array}$ \\
\hline
\end{tabular}


The minority wage gap was also explored as a trend during the past thirty-five years. Figure 1 displays the number of minorities in ARL libraries over the years. The number stayed around 10 percent from 1980 to 1995, but it has increased gradually to approximately 15 percent during the past fifteen to twenty years.
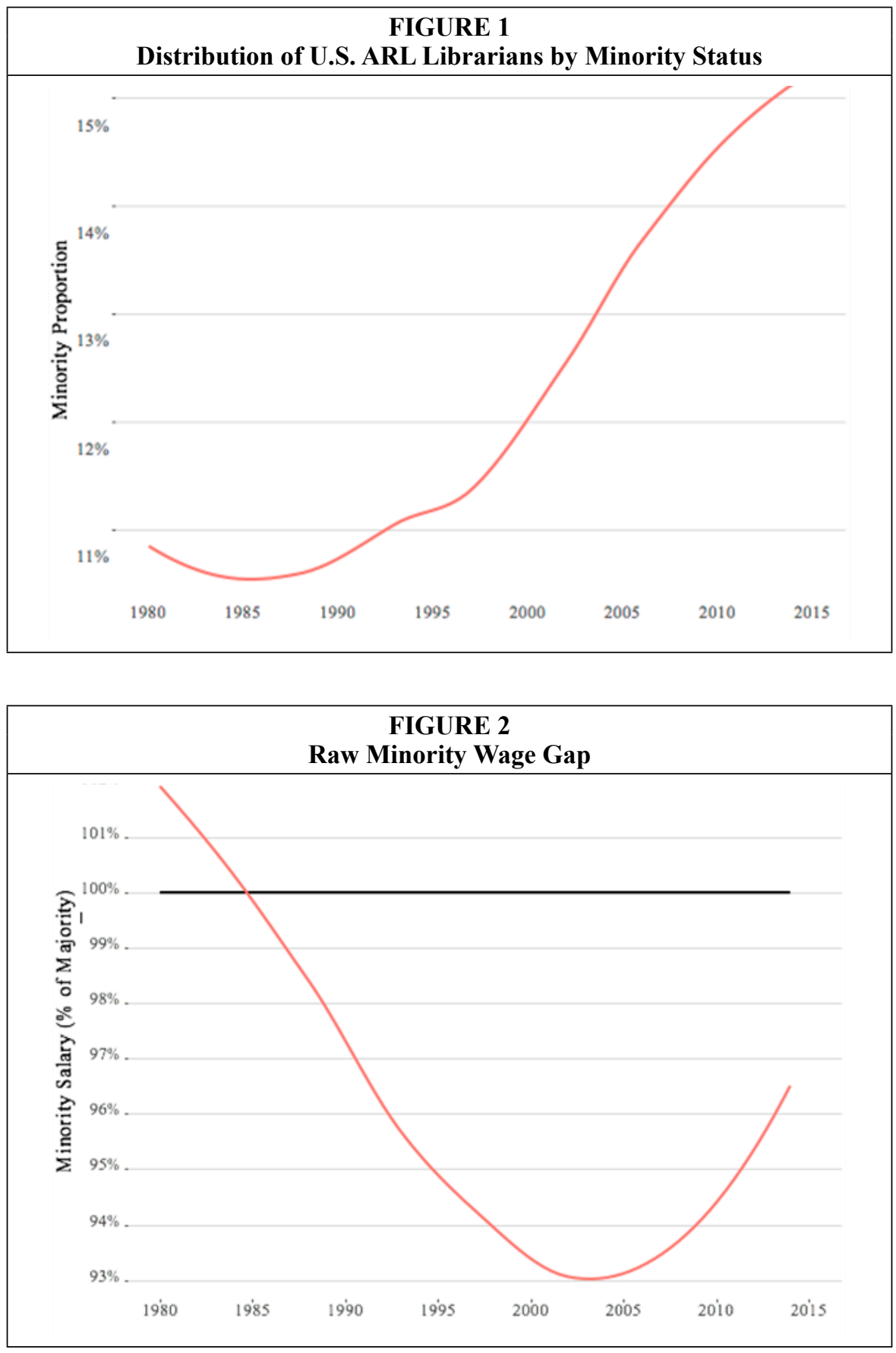


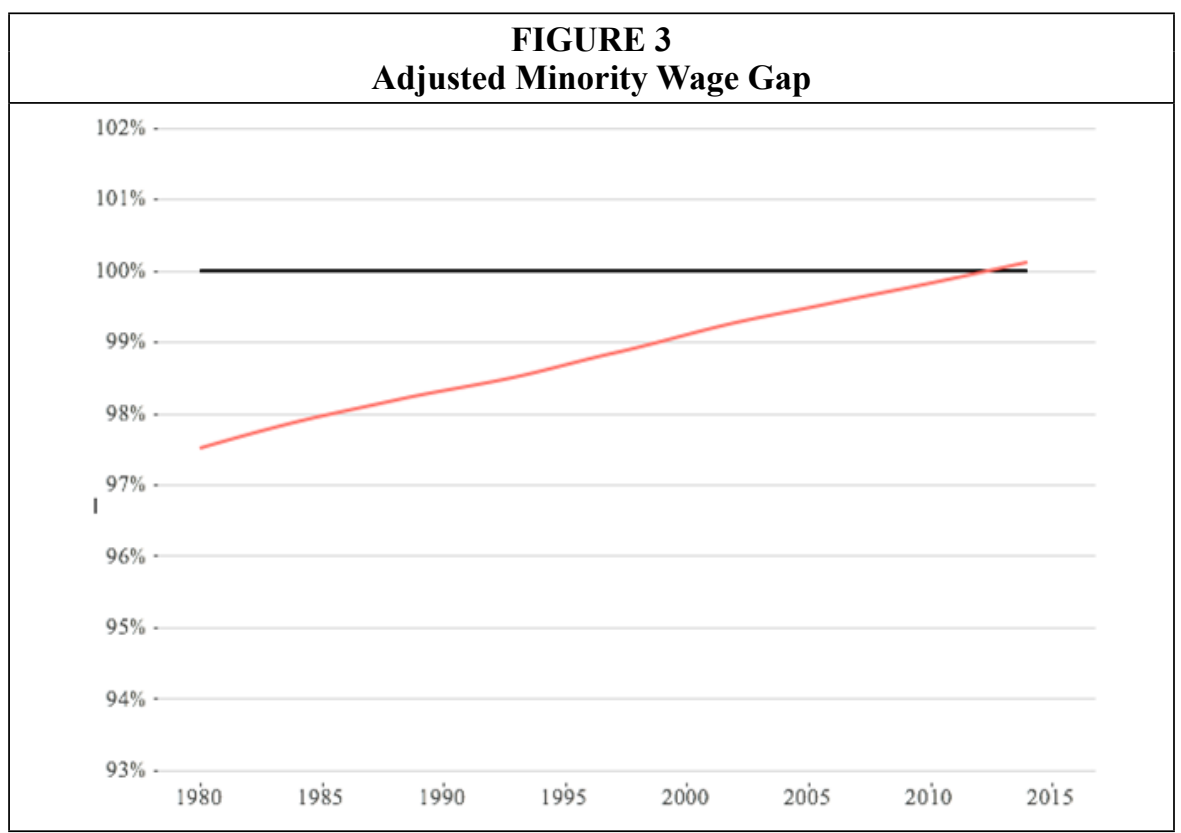

Figure 2 displays the raw wage gap, and figure 3 displays the adjusted wage gap. As figure 2 shows, it appeared that minorities were actually earning more than nonminorities in the 1980s, but when the adjusted model was applied (see figure 3), the graph reversed to show that minorities earned significantly less than nonminorities in the 1980s and their salary gradually increased over the years.

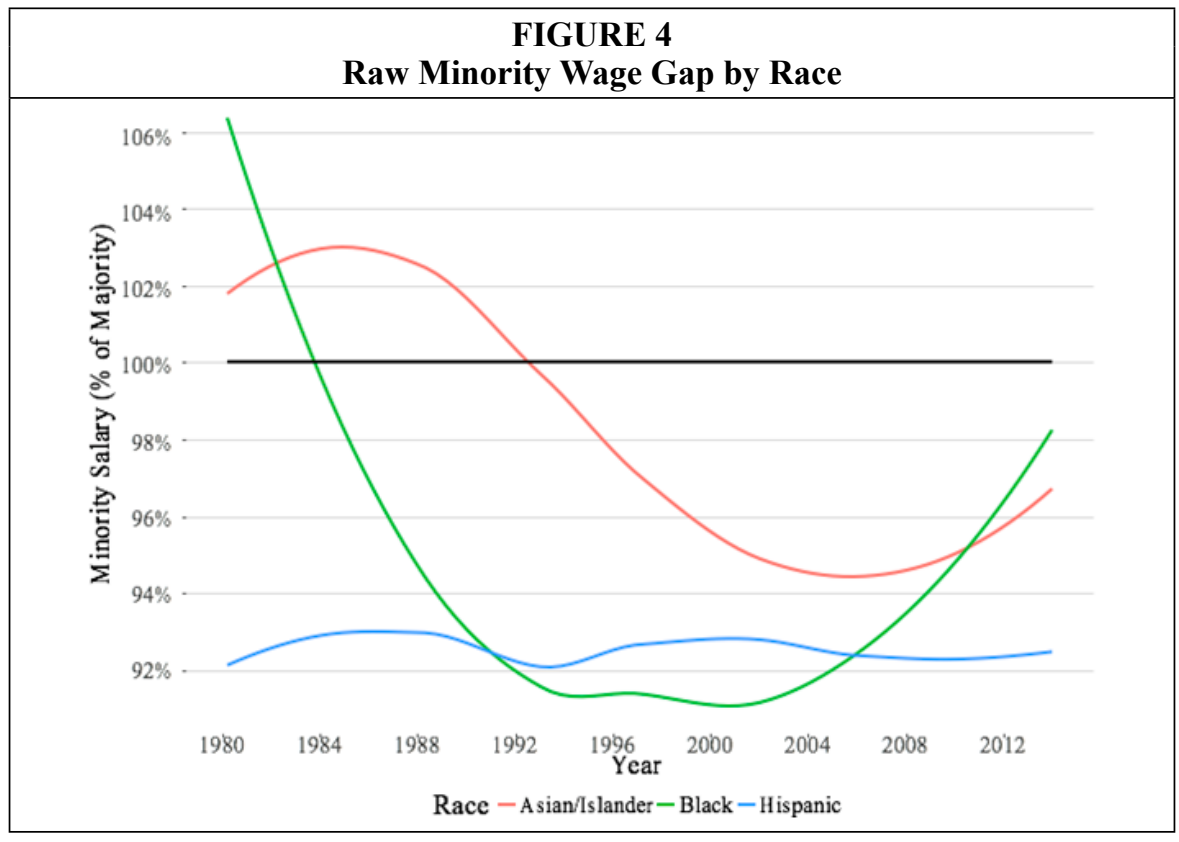


Finally, researchers further examined trends related to wage differences for the three racial groups outlined earlier: blacks, Asians/Pacific Islanders, and Hispanics. Figure 4 shows the raw wage gap for these groups, and figure 5 shows the adjusted wage gap. While blacks and Asians/Pacific Islanders show a gradual trend upward to close the gap, the trend for Hispanics has been consistently lower, and the gap between Hispanics and whites appears to be widening rather than closing.

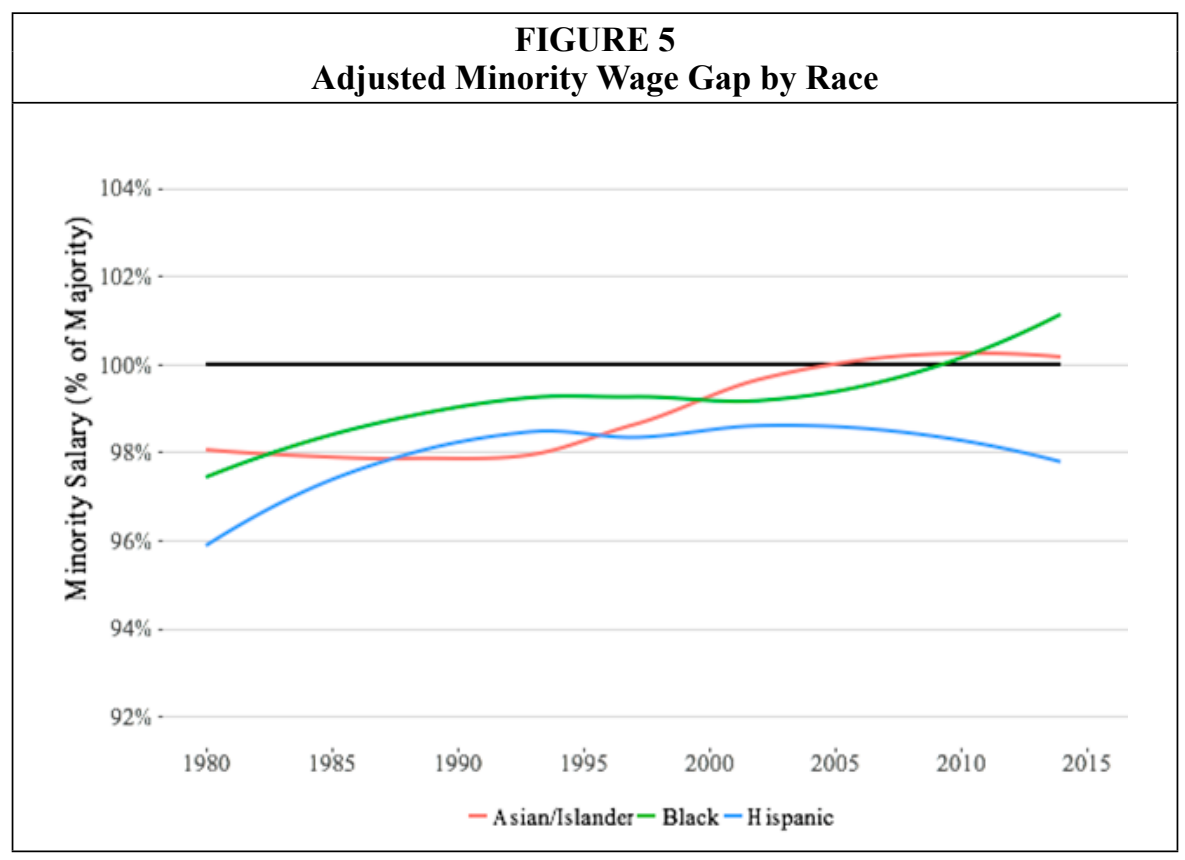

\section{Discussion}

Regarding the current state of the racial wage gap, after controlling for institution, years of experience, years of experience squared, position, sex, law/medical library, and location, there were no significant differences found in wage between minorities and nonminorities. Additionally, when the gap was examined between racial groups, there was no significant difference between any of the individual racial groups (Asians/ Pacific Islanders, blacks, and Hispanics) and nonminorities. However, despite the fact that these tests were not statistically significant, it is important to note that Hispanics were approaching the level of statistical significance $(P=.09)$, appearing to earn substantially less than nonminorities. The trend data also shows that Hispanics have been consistently earning less over the past thirty-five years, indicating that the gap may be widening for Hispanics rather than closing (see figure 5).

The implications of these results are primarily very positive. Overall, the gap between minority and nonminority librarians in ARL libraries has closed, supporting Dewey's assertion that ARL libraries have indeed made great progress toward racial equality among their librarians. ${ }^{40}$ These results show the improvement over the years. Although this data does not include the variables to look at this empirically, it can be argued that this decrease in the racial wage gap provides evidence of the effectiveness of the various programs and initiatives ARL has created to promote racial equality. However, these results also indicate that special attention should be given to ensure that Hispanics also receive equal pay. 
Additionally, as indicated by the results and discussed in the literature review, more attention needs to be given to the number of minority librarians in ARL libraries. While the number has been gradually increasing since 2000 to approximately 15 percent, this number is still well below the national average (26.4 percent) of minorities who earn advanced degrees. ${ }^{41}$ While the literature review presented ideas of what Master's in Library and Information Science (MLIS) schools can do to remedy this, ${ }^{42}$ professional libraries can help fix this gap by making diversity more apparent on their websites and increasing the number of racially diverse librarians available to serve as mentors for students. ${ }^{43}$ Additionally, as many students who decide to pursue MLIS degrees have first worked in a library, libraries can set goals of hiring racially diverse student employees and interns.

Regarding the limitations of the study, while the sample was a particularly good representation of professional ARL librarians, it cannot be generalized to all librarians or even to all academic librarians. ARL libraries are unique in many ways, including the programs and initiatives they have created to foster racial equality. Other libraries that do not have such programs may not have the racial equality that ARL libraries have. Future research should apply a similar methodology to other libraries to gain an understanding of the racial wage gap in other contexts. Similarly, while this study reviewed some of the current recruitment and retention efforts in ARL libraries, it did not analyze these efforts or the results of these efforts. A more in-depth look the specific outcomes of these programs should be considered in future studies.

\section{Conclusion}

Overall, ARL libraries have done an outstanding job of fostering racial equality in pay. According to the analysis, there is no longer a statistically significant wage gap between nonminority and minority librarians in ARL libraries. The data does show, however, that the wage gap between Hispanics and whites may be approaching statistical significance. Additionally, the trend data indicates that the gap between Hispanics and nonminorities may be widening rather than closing. Future studies should continue to specifically investigate the wage gap between nonminorities and Hispanics.

Factors beyond the wage gap need to be taken into account when evaluating racial equality among ARL librarians. The number of minority ARL employees is still fairly low compared to the overall population. Future research and outreach efforts should seek to remedy this. ARL libraries should continue to create and improve initiatives to foster racial equality, particularly for Hispanics. However, as demonstrated by the trend data, ARL has made great steps in the last thirty years toward decreasing the pay gap between minorities and nonminorities as well as increasing the representation of minorities in libraries. While there is still more work to be done-specifically, ensuring that Hispanics receive equal pay and continuing to increase the number of minorities in ARL libraries-overall, ARL libraries appear to be well on their way to ensuring racial equality in pay for their librarians.

\section{Notes}

1. Julia Blixrud and Lee Anne George, "Celebrating Seventy Years of the Association of Research Libraries, 1932-2002," Association of Research Libraries (2008): 20.

2. Ibid., 20.

3. Association of Research Libraries, "Initiative to Recruit a Diverse Workforce," available online at $w w w$.arl.org/leadership-recruitment/diversity-recruitment/initiative-to-recruit-adiverse-workforce-irdw\# [accessed 18 February 2016].

4. Association of Research Libraries, "Leadership \& Career Development Program," available online at www.arl.org/leadership-recruitment/diversity-recruitment/leadership-careerdevelopment-program\#.WMrJFxIrJmA [access 18 February 2016]. 
5. ARL, "Initiative to Recruit a Diverse Workforce."

6. Barbara I. Dewey, "The Imperative for Diversity: ARL's Progress and Role," portal: Libraries $\mathcal{E}$ the Academy 9, no. 3 (2009): 355-61; Maureen Sullivan, "Duane Webster's Contribution to Organization Development in Academic and Research Libraries," portal: Libraries $\mathcal{E}$ the Academy 9, no. 3 (2009): 313-16.

7. Duane E. Webster and W. Putnam, "A Survey of the Recruitment, Staff Development, and Minority Employment Practices of Research Libraries," Association of Research Libraries (1972): 8.

8. Dewey, "The Imperative for Diversity," 355.

9. Ibid., 355.

10. Lori S. Mestre, "Visibility of Diversity within Association of Research Libraries Websites," Journal of Academic Librarianship 37, no. 2 (2011): 101.

11. Ibid., 106.

12. Ibid., 107.

13. Renee E. Franklin and Paul T. Jaeger, "The Virtuous Circle: Increasing Diversity in LIS Faculties to Create More Inclusive Library Services and Outreach," Education Libraries 30, no. 1 (2007): 20-26.

14. Kyung-Sun Kim and Sei-Ching Joanna Sin, "Recruiting and Retaining Students of Color in LIS Programs: Perspectives of Library and Information Professionals," Journal of Education for Library E Information Science 47, no. 2 (2006): 81.

15. Ibid., 82.

16. Ibid., 81 .

17. Ibid., 89 .

18. Ibid., 91.

19. Denice Adkins, "Latino Librarians on Becoming LIS Educators: An Exploratory Investigation of the Barriers in Recruiting Latino Faculty," Journal of Education for Library E Information Science 45, no. 2 (2004): 154-59.

20. David L. Alexander, "American Indian Studies, Multiculturalism, and the Academic Library," College E Research Libraries 74, no. 1 (2013): 60-68.

21. Karin L. Griffin, "Pursuing Tenure and Promotion in the Academy: A Librarian's Cautionary Tale," Negro Educational Review 64, no. 1-4 (2013): 90.

22. Ibid., 89-90.

23. Jennifer Craft Morgan, Brandy Farrar, and Irene Owens, "Documenting Diversity among Working LIS Graduates," Library Trends 58, no. 2 (2009): 192-214.

24. Blixrud and George, "Celebrating Seventy Years," 21.

25. Darren Sweeper and Steven A. Smith, "Assessing the Impact of Gender and Race on Earnings in the Library Science Labor Market," College E Research Libraries 71, no. 2 (2010): 171-83.

26. Ibid., 171-83.

27. Ibid., 175.

28. Javed Ashraf, "The Influence of Gender on Faculty Salaries in the United States, 1969-89," Applied Economics 28, no. 7 (1996): 857-64; Debra A. Barbezat, "The Effect of Collective Bargaining on Salaries in Higher Education," ILR Review 42, no. 3 (1989): 443-55; Debra A. Barbezat, "Updating Estimates of Male-Female Salary Differentials in the Academic Labor Market," Economics Letters 36, no. 2 (1991): 191-95; M.L. Bellas, "Faculty Salaries: Still a Cost of Being Female?" Social Science Quarterly 74, no. 1 (1993): 62-75; Gayle D. Riggs and Lynn Dwyer, "Salary Discrimination by Black Males?" American Journal of Economics and Sociology 54, no. 2 (1995): 231-37.

29. Robert K. Toutkoushian, Marcia L. Bellas, and John V. Moore, "The Interaction Effects of Gender, Race, and Marital Status on Faculty Salaries," Journal of Higher Education 78, no. 5 (2007): 572-601.

30. Quinn Galbraith, Michael Groesbeck, and Heather Kelley, “The Gender Wage Gap in ARL Libraries" (unpublished manuscript, Brigham Young University, 2017).

31. Linda A. Renzulli, Linda Grant, and Sheetija Kathuria, "Race, Gender, and the Wage Gap: Comparing Faculty Salaries in Predominately White and Historically Black Colleges and Universities," Gender E Society 20, no. 4 (2006): 491-510.

32. David R. Dowell, "Sex and Salary in a Female Dominated Profession," Journal of Academic Librarianship 14, no. 2 (May 1988): 92.

33. Bonnie G. Mani, "The Human Capital Model and Federal Employees Pay: Gender, Veteran Status, and Occupation," Gender Issues 30, no. 1-4 (2013): 27.

34. Galbraith, Groesbeck, and Kelley, "The Gender Wage Gap in ARL Libraries."

35. Sonja Lyubomirsky, Laura King, and Ed Diener, "The Benefits of Frequent Positive Affect: Does Happiness Lead to Success?" Psychological Bulletin 131, no. 6 (2005): 803-55.

36. Hannah Riley Bowles and Linda Babcock, "How Can Women Escape the Compensation Negotiation Dilemma? Relational Accounts Are One Answer," Psychology of Women Quarterly 37, no. 1 (2013): 80-96. 
Is There a Racial Wage Gap in Research Libraries? 875

37. Joya Misra, Michelle Budig, and Irene Boeckmann, "Work-Family Policies and the Effects of Children on Women's Employment Hours and Wages," Community, Work \& Family 14, no. 2 (2011): 139-57.

38. Martha S. Hill, "The Wage Effects of Marital Status and Children," Journal of Human Resources 14, no. 4 (1979): 579-94.

39. Sweeper and Smith, "Assessing the Impact," 172.

40. Dewey, "The Imperative for Diversity," 360.

41. Kim and Sin, "Recruiting and Retaining Students of Color in LIS Programs," 81.

42. Ibid., 89-91.

43. Mestre, "Visibility of Diversity," 101-08. 